\title{
Medical Teachers Appraisal. New challenge for European Family Medicine Teachers
}

\author{
Francesco Carelli \\ Professor of Family Medicine EURACT Council
}

Corresponding author: Francesco Carelli, Professor of Family Medicine EURACT Council.

Received date: November 17, 2021; Accepted date: December 30, 2021; Published date: January 07, 2021

Citation: Francesco Carelli, (2022). Medical Teachers Appraisal. New challenge for European Family Medicine Teachers. Archives of Medical Case Reports and Case Study, 5(2); DOI:10.31579/2692-9392/094

Copyright: () 2022 Francesco Carelli, This is an open access article distributed under the Creative Commons Attribution License, which permits unrestricted use, distribution, and reproduction in any medium, provided the original work is properly cited.

\begin{abstract}
:
A professional appraisal can be defined as the process whereby an appraiser examines and evaluates an appraisee's work by comparing it with pre-set standards [1]. This process is generally designed to encourage the professional to reflect on his or her work and to provide evidence that the required standards are being achieved
\end{abstract}

Key words: staphylococcus; escherichia coli; klebsiella; proteus; enterobacteria

\section{Introduction:}

A professional appraisal can be defined as the process whereby an appraiser examines and evaluates an appraisee's work by comparing it with pre-set standards [1]. This process is generally designed to encourage the professional to reflect on his or her work and to provide evidence that the required standards are being achieved.

A recent example about use of appraisal is the process for the appraisal of teaching performance in General Practice/Family Medicine [GP/FM] which has been developed by EURACT, the European Academy of Teachers in GP/FM in collaboration with other partners and funded by the Leonardo da Vinci Programme of the EU $[8,9]$.

Family Medicine is characterized by its specific set of knowledges, skills and attitudes. While family medicine is a young specialty in most European countries, in a few countries it is still not so recognized. Therefore, it is necessary not only to demonstrate the values of family medicine, but also to continue the positive development of training programmes for current and future general practitioners/family physicians.

The European Academy of Teachers in General Practice and Family Medicine (EURACT) has developed a model of an international appraisal of family medicine teachers.

The introduction of this Appraisal Portfolio has a triple purpose:

1. To support, develop and recognise the standard of the individual trainer/teacher

2. To demonstrate the existing standards of education/ training in GP/FM in Europe and to enable further development
3. To enable the coordination of GP/FM training throughout the countries in the EU ( key factor )

EURACT's 'Framework for Continuing Educational Development of Trainers in GP/FM in Europe' has been the background document for the development of the appraisal process for European Family Medicine Teachers. Teachers of FM/GP will present evidence to demonstrate how the competencies as teacher identified in the framework are being achieved. Applications are made for two levels of competence competent or expert, with the assessment paradigm transformed as moving from competence to expertise. The evidence is peer reviewed electronically and a decision reached as to whether the competencies have been achieved. Schemes for the type of evidence required have been made and descriptors provided for the standards required for the award of 'competent' or 'expert'. [10].

This is a developing field and an important ongoing work is done to review the effectiveness of appraisal in supporting doctors in their professional teaching development and as a tool for medical regulation. Appraisal in large has been used increasingly over the years in medicine in an increasing number of Countries and now forms the basis for the revalidation of doctors in UK and other Countries. Revalidation is the process by which licensed doctors should demonstrate that they remain up to date and fit to practise, by showing they can self-correct in terms of learning. Revalidation is based both on clinical governance processes and regular annual appraisal and occurs every a fixed number of years. In UK, the GMC is said to be the first medical regulator in the world to implement such a comprehensive compulsory revalidation process [2]. 
The British Medical Association, the UK's professional body for doctors, has defined the overall aim of appraisal (its own definition) as a process of facilitated self-review supported by information gathered from the full scope of a doctor's work [3].

In addition to satisfying the need for revalidation, appraisal can be used to enable doctors to reflect on their practice, plan their professional development, identify learning needs and ensure that they are working in line with the priorities of their organisation [3].

In this EURACT Appraisal Procedure for Family Medicine Teachers, the applicants must fulfil 9 on 13 domains:

- Learning environment

- Patient safety

- Management of learning

- Educational resources

- Teaching skills

- Educational supervision

- Management of problems

- Assessment and feedback

- Teaching theory

- Working in educational teams

- The curriculum

- Educational research

- Quality improvement

One of the challenges of implementing a nationwide system is that the processes may be applied in different ways in different settings.

Work is ongoing to ensure that the processes surrounding revalidation are as robust and evidence based as possible given the current level of research in this area. A pilot study of enhanced appraisal (5) was done prior to the implementation of revalidation and this found improvements in the quality of appraisal as measured by doctor's participation in significant event reviewes, case reviewes and the feedback from appraisees on the quality of appraisals. Over $80 \%$ of the responding participating organisations and over $70 \%$ of the responsible officers expected the full roll out of revalidation to lead to improved patient safety, improved quality of care and improvements in the patient experience.

\section{References}

1. http://bma.org.uk/support-at-work/appraisals/what-is-a-medicalappraisal

2. http://www.gmc-uk.org/guidance/good_medical_practice.asp

3. http://www.gmc-uk.org/doctors/revalidation/9611.asp

4. Webster M. McLaughlan J. Revalidation Pathfinders Report July 2011 UK Department of Health

5. Wright $\mathrm{C} 1$, Richards $\mathrm{SH}$, et al. Multisource feedback in evaluating the performance of doctors: the example of the UK General Medical Council patient and colleague questionnaires. Acad Med. 2012 Dec;87(12):1668-78

6. Leonardo da Vinci Programme: Transfer of Innovation Continuing Educational Development and Harmonisation of Expert Teachers in General Practice/Family Medicine in Europe through a systematic process of quality improvement (CEDinGPII)Project $n^{\circ}$ : 2013-1PL1-LEO05-37537 Period of realisation: 01/01/2014 - 31/12/2015 http://zizce.edu.pl/cedingp2/

7. Framework for Continuing Educational Development of Trainers in GP/FM in Europe http://www.euract.eu/officialdocuments/finish/3-official-documents/241-framework-forcontinuing-educational-development-of-trainers-in-generalpractice-in-europe-cedingp

8. Buchanan J. Appraisal of GP Teachers. EURACT Messenger, Issue 2, November 2014; www.euract.eu

9. http://euract-appraisal.woncaeurope.org/

10. Svab I., Windak A., Buchanan J. et al. Handbook for Appraisers of teaching performance, 2015 - www.euract.eu
This work is licensed under Creative Commons Attribution 4.0 License
To Submit Your Article Click Here: Submit Manuscript

DOI:10.31579/2692-9392/094
Ready to submit your research? Choose Auctores and benefit from:

$>$ fast, convenient online submission

$>$ rigorous peer review by experienced research in your field

$>$ rapid publication on acceptance

$>$ authors retain copyrights

$>$ unique DOI for all articles

$>$ immediate, unrestricted online access

At Auctores, research is always in progress.

Learn more https://www.auctoresonline.org/journals/archives-of-medical-casereports-and-case-study 
